\title{
Direct Liquefaction of 2 South African Bituminous Coal Fines and Their Beneficiated Float Fractions
}

\author{
R.C. Uwaoma, C.A. Strydom, R.H. Matjie and J.R. Bunt
}

\begin{abstract}
The direct liquefaction of South African coal fines and their density separated (float) fractions were carried out under moderate conditions in a laboratory autoclave. The liquefaction temperature ranged between 380 and $420 \mathrm{oC}$, using tetralin as a solvent and an initial nitrogen gas pressure of $3 \mathrm{MPa}$. Results from the liquefaction tests showed that the carbon conversion and oil yields were high for the float fractions when compared to the coal fines. Waterberg and Highveld coal float fractions achieved a high carbon conversion of $50.7 \mathrm{wt} \%$ daf and $52.7 \mathrm{wt} \%$ daf respectively, compared with $<42 \mathrm{wt} \%$ daf carbon conversion for the coal fines. The effectiveness of the carbon conversion was correlated with the reactive macerals and the surface area of the individual samples. It was observed that the density separated coal fraction, which has a higher surface area, higher vitrinite content and higher reactive macerals content yielded higher extraction efficiencies. The residues and extracts obtained during the liquefaction tests were characterised using nuclear magnetic resonance spectroscopy, proximate and ultimate analyses. The analytical results indicated that the residue showed a slight decrease in calorific value and aliphatic components, with a lower $\mathrm{H} / \mathrm{C}$ ratio and a higher ash content. Also, the results showed that using the float fractions of South African coals at a moderate liquefaction temperature could be beneficial in the production of liquid fuel.
\end{abstract}

Index Terms - Direct Liquefaction, South African Bituminous Coal Fines.

\section{INTRODUCTION}

The South Africa coal mining industry produced approximately 307 million tons low-rank bituminous coal in 2007 [1]. The local thermo-chemical processes utilise coal for oils, petrochemicals and steam generation. More than 10 million tons coal fine discards per year are an unavoidable by-product of the production of coal from the South African

R.C. Uwaoma, Centre of Excellence in Carbon-based Fuels, School of Physical and Chemical Sciences, North-West University, Potchefstroom Campus, Private Bag X6001, Potchefstroom 2520, South Africa.

C.A. Strydom, Centre of Excellence in Carbon-based Fuels, School of Physical and Chemical Sciences, North-West University, Potchefstroom Campus, Private Bag X6001, Potchefstroom 2520, South Africa.

R.H. Matjie, Centre of Excellence in Carbon-based Fuels, School of Chemical and Minerals Engineering, North-West University, Potchefstroom Campus, Private Bag X6001, Potchefstroom 2520, South Africa

J.R. Bunt, Centre of Excellence in Carbon-based Fuels, School of Chemical and Minerals Engineering, North-West University, Potchefstroom Campus, Private Bag X6001, Potchefstroom 2520, South Africa. coal mine sand utilisation of the low-rank bituminous coal in the thermo-chemical processes [2]. Costs that are associated with the disposal and handling of the fine coal discards exceed the fuel value of these fines. In addition, the coal fine discards have negative environmental impacts, including dust, spontaneous combustion and acid mine drainage problems. However, the composition of coal fine discards is similar to that of the feed coals to the thermo- chemical processes in terms of coal properties.

Liquefaction is one of the thermo-chemical processes used in the conversion of coal to useful products. During the liquefaction of coals, the extraction yield not only depends on the rank of the coal, but also on the solvent types and extraction temperature [3-5]. The solvent acts as a means for transferring hydrogen to coal during the liquefaction process [6]. The different types of coals show distinctions in reactivity and yield during the liquefaction process [9-7]. Thus, different macerals groups or organic matter in coal are expected to show different reactivities and yields during the liquefaction process $[8,9,10]$. There is no literature on the liquefaction of South African coal fines, coal fine discards and their float fractions produced during the density separation of the coals using a tetralin solvent.

Understanding the behaviour of different macerals in South African density separated caking and non-caking coals will assist in optimizing and identifying the influence of the maceral group during the liquefaction process. The liquefaction of South African Waterberg and Highveld bituminous coals and their float fractions with all contains various ash yields and vitrinite concentrations, using a tetralin solvent, were investigated. The objectives of this paper are: (1) to investigate the utilization of float fractions produced from density separation of two South African bituminous coal fines on the overall liquefaction process; (2) to investigate the possibility of reduction of the amount of coal fine discards by utilisation in the direct coal liquefaction process; (3) to investigate the effect of temperature on the oil, gas, pre-ashpathene, and other products distribution, carbon conversion and residual coals productions during the liquefaction of the float fractions of South African coal fines.

\section{METHODOLOGY}

\section{A. Sample preparation and characterization}

The Highveld bituminous coal samples used in this 
investigation were received from the dumping sites of discard coal fines originating from the Highveld coalfield, which is situated in the Mpumalanga Province in Republic of South Africa, whilst the Waterberg bituminous coal samples used in this investigation was received from stock piles of discard coal fines originating from the Waterberg coalfield in the Limpopo Province of the Republic of South Africa. The particle sizes of the coal samples ranged from a fine powder to approximately 20 $\mathrm{mm}$. The samples were sieved to obtain the $>0.5 \mathrm{~mm}$ coal particles before density separation. The coal samples were oven-dried and stored under nitrogen to prevent oxidation before further use.

The density separation was done on the coarse coal fines and as follows: The $>0.5 \mathrm{~mm}$ fraction density separated to produce a float fraction $(<1.5 \mathrm{~g} \mathrm{~cm}-3)$, middling fraction (1.5-1.8 $\mathrm{g}$ $\mathrm{cm}-3)$ and sink fraction $(>1.8 \mathrm{~g} \mathrm{~cm}-3)$. The density separation was conducted on run of mine coals to produce organic matter-rich materials (float fractions) and mineral matter-rich materials (sink fractions).

The coal fines and float fractions were characterized by means of proximate analyses (Inherent moisture ISO11722:1999, Ash content ISO1171:2010, Volatile matter ISO: 562:2010), ultimate analysis (based on ISO 29541) and petrographic analysis (based on ISO 7404-4) to obtain the conventional and petrographic properties. Surface area measurements were obtained using a Micrometrics ASAP 2020 surface area and porosity analyser. The Dubinin-Radushkevich (D-R) and Horvath-Kawazoe (H-K) models were used to obtain the micropore surface area, maximum pore volume and median pore width [11].

\section{B. Liquefaction Experiments and Extraction of liquefaction products}

The pulverized samples $(212 \mu \mathrm{m})$ were dried in an oven at 80 ${ }^{\circ} \mathrm{C}$ for 24 hours to reduce the inherent moisture contents of the samples. The direct liquefaction experiments were carried out in an ASS316 high-pressure stainless steel autoclave system (300 mL capacity, $90 \mathrm{~mm}$ diameter and $150 \mathrm{~mm}$ height) under $\mathrm{N}_{2}$. The solvent used was tetralin (THN, purity $\geq 99.5$. A mass ratio of 3:1 solvent to coal was used in the experiments. Before pressurizing the reactor with $\mathrm{N}_{2}$ to a fixed initial pressure of 3 MPa a leak test was performed. The reactor was firstly purged then sealed and pressurized with $\mathrm{N}_{2}$. The autoclave was heated to the operational temperature $\left(380,400\right.$, and $\left.420{ }^{\circ} \mathrm{C}\right)$ and kept for a holding time of $20 \mathrm{~min}$. A heating rate of approximately $4.0{ }^{\circ} \mathrm{C} / \mathrm{min}$ was used during the ramping stage to the desired temperatures, and the stirring rate was kept constant at $300 \mathrm{rpm}$. At the end of the desired reaction period, the autoclave was air cooled to ambient temperature. The solid-liquid mixture (consisting of the coal residue, extract, and solvent) was collected from the autoclave and weighed (to calculate the yield of gaseous products). This procedure was repeated more than three times for each operational temperature.

A series of solvent extraction tests were carried out on the liquid mixture using a reflux system with two solvents at $85^{\circ} \mathrm{C}$ for 1 hour and a solvent/liquid product ratio of 1:1. The experimental procedure involves the extraction with tetrahydrofuran (THF) and n-hexane in sequence to separate the products from the organic liquids (extracts). The THF-insoluble part of the liquid residue was labelled (THFI) and represents the unreacted coal residues. The THF-soluble part of the liquid residue (THFI) was further extracted with hexane. The hexane-soluble (HS) product contained the oil part of the products and the solvent. The hexane-insoluble (HI) part of the extraction was labelled pre-asphaltenes (PAA) products. All the product yields were calculated on a dry ash free basis (daf).

\section{RESULTS AND DISCUSSION}

\section{A. Characterization of the feed and the float fractions}

The results of the proximate and ultimate analyses and the ash analysis for the float fractions are presented in Table 1. The Highveld and Waterberg coal fines samples exhibited relatively low volatile matter contents of $17.7 \%$ (adb) and $25.7 \%$ (adb) respectively. The ash contents of the two coal fines samples were found to be relatively high with Highveld and Waterberg coals having ash contents of 42.0 wt.\% (adb) and 30.0 wt.\% (adb) respectively. The moisture contents of the Highveld and Waterberg coal fines were 3.0 wt. $\%$ and 3.1 wt. $\%$ (adb) respectively. The calorific value of the coal fines was found to be $17.7 \mathrm{MJ} / \mathrm{kg}$ for Highveld coal fine sand 21.6 $\mathrm{MJ} / \mathrm{kg}$ for Waterberg coal fines.

As expected, the beneficiated samples showed a difference from the coal fines material with the float fractions having a slight increase in the volatile matter, carbon content and in calorific value. The values of volatile matter (adb) for Highveld and Waterberg float fractions were observed to be $25.4 \mathrm{wt}$. \% and 30.2 wt. \% respectively. Fixed carbon contents in Highveld and Waterberg float fractions were found to be 46 wt. $\%$ and 51.0 wt. \%. The calorific values of the Highveld and Waterberg float fractions were $25.7 \mathrm{MJ} / \mathrm{kg}$ and $27.2 \mathrm{MJ} / \mathrm{kg}$. The Highveld float fraction $\left(1.5 \mathrm{~g} / \mathrm{cm}^{3}\right)$ contained $11.8 \mathrm{wt} . \%$ ash content $(\mathrm{adb})$, whilst the Waterberg float $\left(1.5 \mathrm{~g} / \mathrm{cm}^{3}\right)$ fraction contained 13.4 wt. $\%$ ash. There was not much difference in the moisture contents of the coal fines and the float fractions of both coal samples. The middlings and the sink materials will not be used further during this study.

Table 1 indicates that the two coal fines samples are rich in elemental carbon (all daf), with contents of $75.5 \mathrm{wt} . \%$ and 77.2 wt. \%. The hydrogen and oxygen contents in the two coal fines were found to be comparable with hydrogen and oxygen contents contained in other South African coals [11-13]. The float fractions of both coals contain relatively high oxygen contents and to some extent high volatile matter contents, which implies that the float fractions of both coal samples contained a relatively higher percentage of polar functional groups, such as carbonyl, carboxyl and hydroxyl groups. The elemental nitrogen and total sulphur contents of the float fractions of both coals were also relatively low. The Highveld and Waterberg float fraction samples showed comparable elemental characteristics with the coal fine samples. The atomic ratio of $\mathrm{H} / \mathrm{C}$ indicates the degree of aromaticity in coal. The ratio can be 
observed in Table 1, which indicated that the Highveld coal fine sand Highveld float fraction samples $\left(1.5 \mathrm{~g} / \mathrm{cm}^{3}\right)$ have $\mathrm{H} / \mathrm{C}$ ratios of 0.94 and 0.90 respectively.

A summary of the surface area and porosity properties of the samples are also given in Table 1. The different analytical methods and models used to obtain the results are also given in Table 1. As shown in Table 1, the Dubinin-Radushkevich (D-R) micropore surface area and the Brunauer-Emmet-Teller (BET) surface area of the coal fines were found to be $104.3 \mathrm{~m}^{2} / \mathrm{g}$ and $66.0 \mathrm{~m}^{2} / \mathrm{g}$ for Waterberg coal fine sand $98.7 \mathrm{~m}^{2} / \mathrm{g}$ and $61.8 \mathrm{~m}^{2} / \mathrm{g}$ for Highveld coal. The surface area of the float fractions are slightly higher than for the other fractions. In the case of the Waterberg float fraction, the surface area were $140.0 \mathrm{~m}^{2} / \mathrm{g}$ and Brunauer-Emmet-Teller (BET) surface area. Whereas, the Highveld float fraction has a (D-R) micropore surface area of $131.0 \mathrm{~m}^{2} / \mathrm{g}$ and a Brunauer-Emmet-Teller (BET) surface area of $76.8 \mathrm{~m}^{2} / \mathrm{g}$.

The petrographic analysis results that are shown in Table 1 $86.4 \mathrm{~m}^{2} / \mathrm{g}$ for (D-R) the micropore surface area and the

reveal that the coal fines were slightly inertinite-rich, with inertinite maceral abundance of $34.9 \mathrm{vol}$. \% (mmb) and 37.7 vol.\% (mmb) for the Highveld and Waterberg coals respectively. The vitrinite macerals content of the Highveld and Waterberg coal fines were 34.9 vol. $\%$ and $39.3 \mathrm{vol} . \%$. (mmb). The liptinite maceral contents (all $\mathrm{mmb}$ ) in the Highveld and Waterberg coal fines were 1.9 vol. \%, and 3.3 vol. \% respectively. When comparing the Highveld and Waterberg coal fines samples with the float (beneficiated) samples, it was observed that there was a slight increase in the vitrinite content of the float fraction with a corresponding decrease in the inertinite content. The liptinite contents of the float fractions also do not show much difference compared with the coal fines samples. The total volume of reactives (TV+TL+RSF) in the Highveld and Waterberg coal fines samples were $59.6 \mathrm{vol}$. \% and 65.4 vol. \% respectively. These values (all mmb) increased for the Highveld float fraction and Waterberg float fraction having 74 vol. $\%$ and 70 vol. \% respectively.

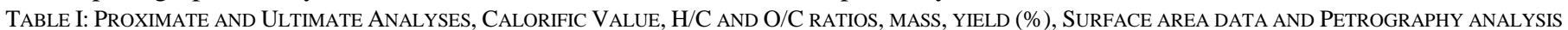
RESULTS OF COAL FINES AND THEIR FLOAT FRACTIONS.

\begin{tabular}{|c|c|c|c|c|c|}
\hline Sample ID/Properties & Method of Analysis & HR & $\mathrm{HF}<1.50$ & WR & $\mathrm{WF}<1.50$ \\
\hline Mass (g) & & 100000 & 25250 & 104800 & 47560 \\
\hline Yield (\%) & & 100 & 38.85 & 100 & 45.7 \\
\hline Cal.Val. (MJ/kg) & ISO 1928:2009 & 17.7 & 25.7 & 21.6 & 27.2 \\
\hline \multicolumn{6}{|c|}{ Proximate Analysis (wt.\%, adb) } \\
\hline Inherent moisture & ISO11722:1999 & 3.0 & 4.1 & 3.1 & 3.4 \\
\hline Ash yield & ISO1171:2010 & 42.0 & 11.8 & 30.2 & 13.4 \\
\hline Volatile matter yield & ISO:562:2010 & 17.7 & 29.4 & 25.7 & 31.2 \\
\hline Fixed carbon & By difference & 37.3 & 54.7 & 41.0 & 52.0 \\
\hline \multicolumn{6}{|c|}{ Ultimate Analysis (wt.\%, dafb) } \\
\hline Carbon & ISO17247:2013 & 75.5 & 75.6 & 77.2 & 77.7 \\
\hline Hydrogen & ISO17247:2013 & 5.9 & 5.7 & 5.4 & 5.1 \\
\hline Nitrogen & ISO17247:2013 & 2.1 & 2.6 & 1.5 & 1.5 \\
\hline Total sulphur content & ISO 19579:2006 & 1.8 & 1.3 & 1.9 & 1.2 \\
\hline Oxygen & (by difference) & 14.9 & 14.7 & 14 & 14.5 \\
\hline $\mathrm{H} / \mathrm{C}$ & & 0.94 & 0.9 & 0.84 & 0.79 \\
\hline $\mathrm{O} / \mathrm{C}$ & & 0.15 & 0.15 & 0.14 & 0.14 \\
\hline \multicolumn{6}{|c|}{$\mathrm{CO}_{2}$ surface area results } \\
\hline BET surface area $\left(\mathrm{m}^{2} / \mathrm{g}\right)$ & & $61.8 \pm 3.0$ & $76.8 \pm 1.9$ & $66.0 \pm 1.0$ & $86.4 \pm 1.2$ \\
\hline H-K Average Micropore & $r(\AA)$ & $3.870 \pm 0.044$ & $3.893 \pm 0.014$ & $3.859 \pm 0.012$ & $3.837 \pm 0.011$ \\
\hline D-R Micropore volume & $\left.\mathrm{n}^{3} / \mathrm{g}\right)$ & $0.0396 \pm 0.002$ & $0.0525 \pm 0.002$ & $0.0418 \pm 0.003$ & $\begin{array}{c}0.0561 \pm \\
0.001\end{array}$ \\
\hline Porosity (\%) ( $3 \AA \leq d_{p} \leq$ & & $3.70 \pm 0.36$ & $4.24 \pm 0.10$ & $3.97 \pm 0.15$ & $5.26 \pm 0.03$ \\
\hline D-R Micropore surface & & $98.7 \pm 5.5$ & $131.0 \pm 5.2$ & $104.3 \pm 7.4$ & $140.0 \pm 2.4$ \\
\hline \multicolumn{6}{|c|}{ Petrography analysis results (vol. $\%, \mathrm{mmb})$} \\
\hline Sample Identification & & HR & $\mathrm{HF}<1.5$ & WR & $\mathrm{WF}<1.5$ \\
\hline Total Vitrinite (TV) & & 34.9 & 58.4 & 39.3 & 51.6 \\
\hline Total Liptinite (Exinite) & & 0.9 & 3.8 & 3.3 & 1.5 \\
\hline Total inertinite (calculat & & 58.7 & 27.7 & 40.7 & 37.8 \\
\hline Reactive Semifusinite ( & & 23.8 & 11.8 & 22.8 & 17.7 \\
\hline$\%$ Mineral Matter (calcu & & 22.9 & 13.1 & 16.7 & 9.1 \\
\hline$\%$ Total Reactives (TV+ & & 59.6 & 74.0 & 65.4 & 70.8 \\
\hline$\%$ Total Inerts (Calculat & & 40.4 & 26.0 & 34.6 & 29.2 \\
\hline \multicolumn{6}{|c|}{ Reflectance properties } \\
\hline Mean vitrinite random $r$ & $\mathrm{e}(\mathrm{Rr}, \%)$ & 0.61 & 0.59 & 0.65 & 0.66 \\
\hline Mean total maceral refle & $\mathrm{Rsc}, \%)$ & 0.65 & 0.63 & 0.69 & 0.7 \\
\hline Rank of coal & & Med C & Med C & Med C & Med C \\
\hline Vitrinite Classification & & Low & Medium & Low & Medium \\
\hline
\end{tabular}




\section{B. Liquefaction Results}

\subsubsection{Effect of coal composition on liquefaction}

The results in Figure 1 show that the chemical and petrographic compositions of the macerals have an effect on the liquefaction compositions. The oil yield in Figure 1 follows the order $\mathrm{HF}>\mathrm{WF}>\mathrm{WR}>\mathrm{HR}$ under N2 atmosphere. Vitrinite was enriched in the Waterberg float fraction and Highveld float fraction, making up about $51.6 \%$ and $58.4 \%$ respectively (Table 1) of all the macerals in the float fractions. The low oil yield of the coal fines samples could be explained by the high inertinite composition of the feed material and the low amount of total reactive macerals (Table 1). The Waterberg and Highveld float fractions showed a high yield which could be attributed to the high vitrinite content, high reactive macerals and high volatile contents (Table 1). Figure 2 shows a positive correlation between the surface area, total reactive macerals, and conversion. This suggests that an increase in the surface area or total reactive macerals leads to an increase in conversion.

\subsubsection{Effect of temperature on conversion}

From Figure 1, it was observed that conversion increased with an increase in temperature. This trend is consistent with the data from a previously reported studies $[14,15]$. The Waterberg and Highveld float fractions achieved a carbon conversion of 50.7 wt. $\%$ and 52.7 wt. $\%$ (all daf) at $420 \mathrm{oC}$. These values were higher when compared to those from the Waterberg and Highveld coal fines, with carbon conversions of $41.7 \mathrm{wt} . \%$ and 41.8 wt. \% (daf) at $420 \mathrm{oC}$. The high conversion of the float fractions could be attributed to beneficiated coal having a higher vitrinite maceral content when compared to the coal fines. The higher carbon conversion of the float fractions indicates that a higher amount of solvent assists in the breakdown of the macromolecular structure of the beneficiated coal matrix leading to a higher conversion.

\subsubsection{Effect of temperature on oil productions}

As it can be seen in Figure 1, similar observations for the conversion were obtained for the oil. The oil yield increased as the temperature of the liquefaction increased. The increase in the oil yield could be as a result of the further breaking down of the pre-asphaltene and residue at higher temperature leading to the formation of more oil and gases. The oil production of the float fractional samples was high when compared to the coal fines samples. The oil yield increased from, $24.7 \mathrm{wt}$. \% to $30 \mathrm{wt}$. $\%$ (daf) for the Waterberg float fraction, and 25.7 wt. \% to 33.9 wt.\% (daf) for the Highveld float fraction at the higher liquefaction temperature.

\subsubsection{Effect of temperature on pre-ashpathene (PAA)} production

It can be seen in Figure 1 that the PAA content decreased with an increase in the liquefaction temperature. As it was established above, at higher temperatures there was an increase in the percentage of oil, which may be as a result of the further breakdown of the coal macromolecule as the temperature increased. The breakup of the coal macromolecules produces free radicals that depolymerize the PAA, thereby increasing the amount of oil yield and subsequently reducing the formation of PAA.

\subsubsection{Effect of temperature on residue production}

Residues are one of the products that are often affected by the liquefaction of coal. As it was seen in Figure 1, the yield of residues decreased as the temperature of the liquefaction increased. The Highveld Float residue reduced from $58 \%$ at 380 $\mathrm{oC}$ to $45.7 \%$ at $420 \mathrm{oC}$. The Waterberg Float residue reduced from $59 \%$ at $380 \mathrm{oC}$ to $50 \%$ at $420 \mathrm{oC}$. The reduction of the residue as temperature increases could be attributed to the depolymerisation of the coal macromolecule at elevated liquefaction temperature leading to high conversion, oil, and gas formation.

\subsubsection{Effect of temperature on gas production}

Figure 1 presents the gas content results from the liquefaction experiments, which shows that the gas yield slightly increased as the temperature of the liquefaction increased. The increase in temperature increases the gas yield of the Waterberg float fraction and Highveld float fractions from $4 \%$ to $6.7 \%$ and $3.6 \%$ to $7.7 \%$ respectively between 380 and $420 \mathrm{oC}$. Rupture of lighter hydrocarbons and secondary reactions, such as cracking, methanation and steam reforming produces more gas at the higher temperatures $[16,17]$. The coal fines and float samples do not show much difference in the gas production. This suggests that the major variable controlling gas formation during the liquefaction process is temperature. 


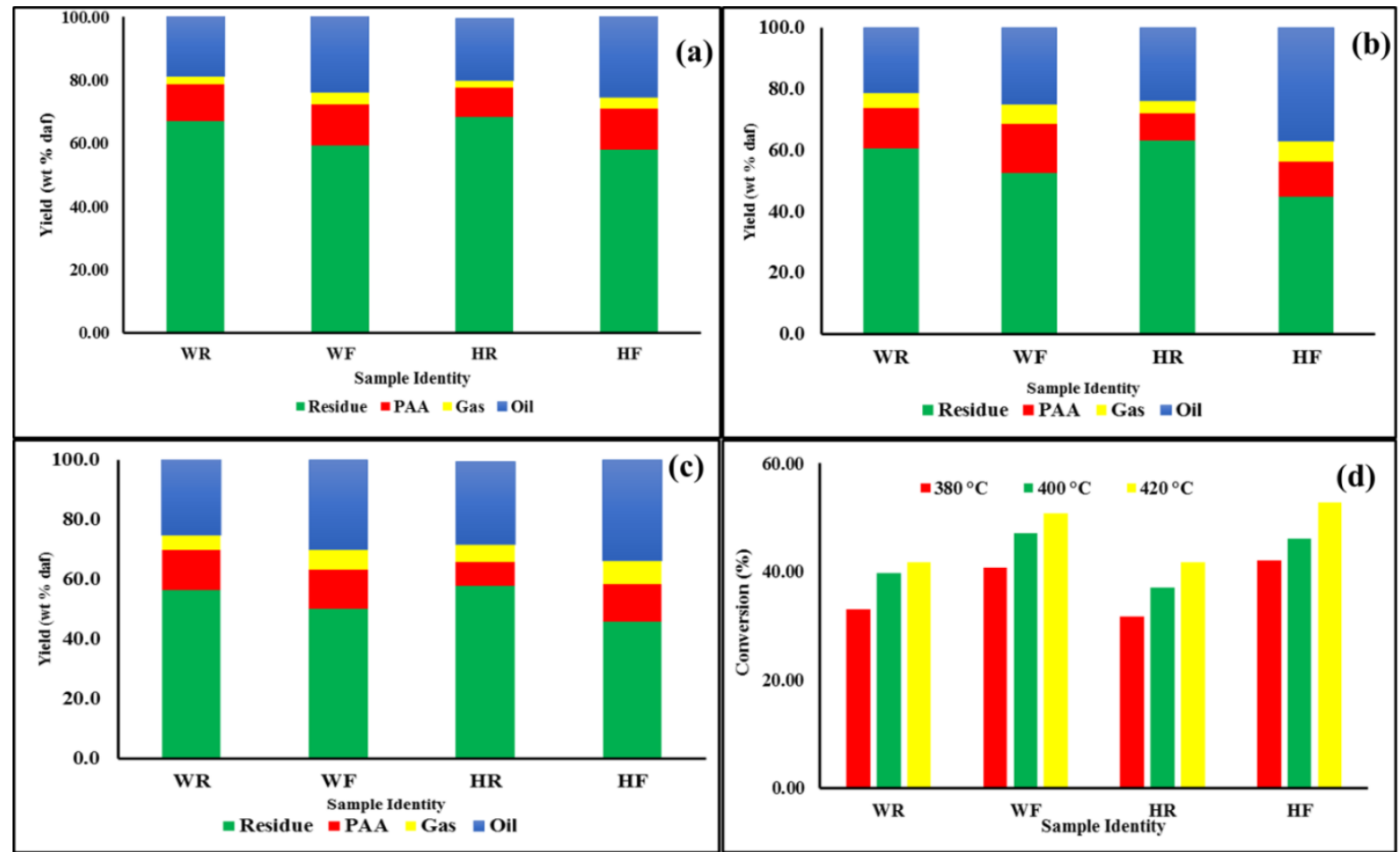

Fig 1: Products distribution of coal fine sand density separation fraction at (a) $380 \mathrm{oC}$, (b) $400 \mathrm{oC}$, (c) $420 \mathrm{oC}$, and (d) Coal conversion at different temperatures. Note: $\mathrm{HR}=$ Highveld coal fines, $\mathrm{HF}<1.5=$ Highveld float, $\mathrm{WR}=$ Waterberg coal fines, $\mathrm{WF}<1.5=\mathrm{Waterberg}$ float.
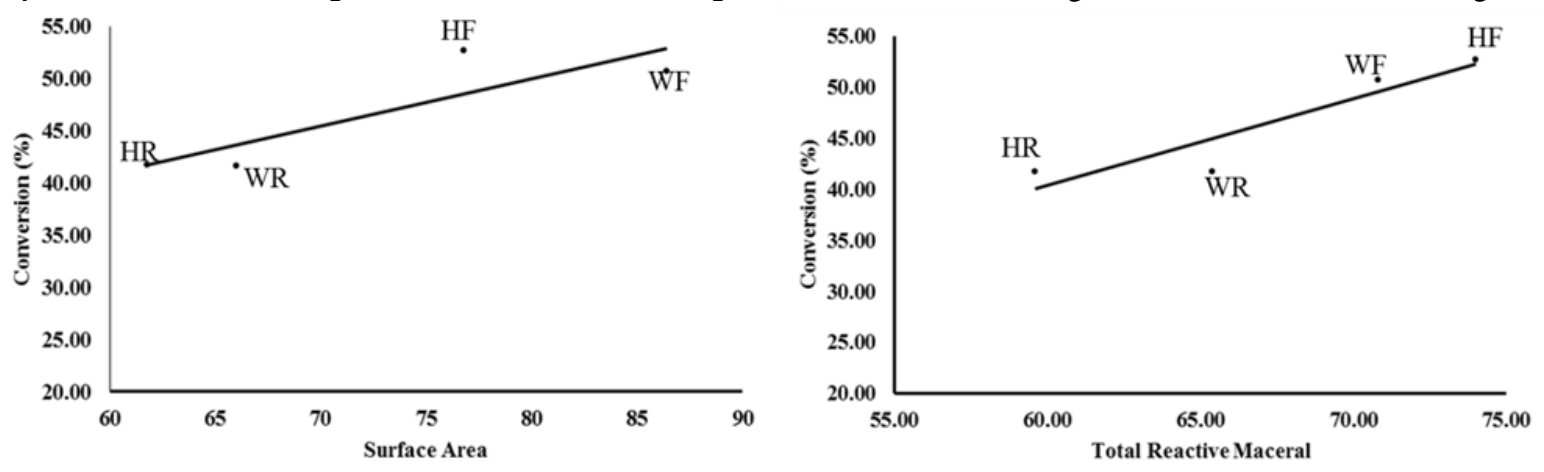

Fig 2: (a) Surface area data vs carbon conversion, and (b) total reactive macerals vs carbon conversions

\section{CONCLUSION}

The direct liquefaction of South African coal fines and their float fractions were investigated with tetralin as solvent, using a laboratory autoclave at a temperature ranging from $380-420 \mathrm{oC}$ under inert $\mathrm{N} 2$ atmosphere with an initial pressure of $3 \mathrm{MPa}$. The results obtained show that using South African coal density separated float fractions at moderate liquefaction temperatures could be beneficial for the production of liquid fuel. Based on the results obtained the following conclusions were made:

- The float fractions show higher CV, surface areas, vitrinite contents and reactive maceral contents with a reduction in ash when compared to the coal fines.

- Higher carbon conversions were achieved from the float fractions in comparison to the coal fines with a corresponding decrease in the amounts of residues at $420 \mathrm{oC}$. An increase in liquefaction temperature increased the carbon conversion and the yield of oil.
- Density separation of coal fines are beneficial to produce a float fraction that may be used as feedstock for direct coal liquefaction. The analytical results obtained from the proposed technology could be used to reduce high costs and volumes of coal fines that are associated with the disposal and handling of coal fines and environmental problems.

\section{ACKNOWLEDGMENT}

The research work presented in this paper is based on the research supported by the South African Research Chairs Initiative of the Department of Science and Technology and National Research Foundation of South Africa (Coal Research Chair Grant No.: 86880 and incentive grant No. 115228). Any opinion, finding or conclusion or recommendation expressed in this material is that of the author(s) and the NRF does not accept any liability in this regard. 


\section{REFERENCES}

[1] Gibson. P. Coal to liquid at Sasol. Kentucky Energy security Summit 2007. http://www.caer.uky.edu/podcast/Gibson-KESummitOct2007r.p df. Assessed 10-05-2017.

[2] Reddick, J.F.; Von Blottnitz, H.; Kothuis, B. A cleaner production assessment of ultr-fine coal waste generated in South Africa. The journal of the Southern African Institute of Mining and Metallurgy, 2007, 107, 55-60.

[3] Masaki, K.; Yoshida, T.; Li, C.; Takanohashi, T.; Saito, I. The effects of pretreatment and the addition of polar compounds on the production of "HyperCoal" from subbituminous coals. Energy \& fuels 2004, 18, 995-1000. https://doi.org/10.1021/ef049970o

[4] Kashimura, N.; Takanohashi, T.; Saito, I. Upgrading the solvent used for the thermal extraction of sub-bituminous coal. Energy \& fuels 2006, 20, 2063-6. https://doi.org/10.1021/ef0601014

[5] Do Kim, S.; Woo, K.J.; Jeong, S.K.; Rhim, Y.J.; Lee, S.H. Production of low ash coal by thermal extraction with N-methyl-2-pyrrolidinone. Korean Journal of Chemical Engineering 2008, 25, 758-63. https://doi.org/10.1007/s11814-008-0124-0

[6] Skowronski, R. P.; Ratto, J. J.; Goldberg, I. B.; Heredy, L. A. Hydrogen incorporation during coal liquefaction. Fuel 1984, 63, 440-448. https://doi.org/10.1016/0016-2361(84)90277-1

[7] Choi, C.Y.; Muntean, J.V.; Thompson, A.R.; Botto, R.E. Characterization of coal macerals using combined chemical and NMR spectroscopic methods. Energy \& fuels 1989, 3(4), 528-33. https://doi.org/10.1021/ef00016a017

[8] Choi, C.Y.; Dyrkacz, G.R. Base-catalyzed separation of coal macerals. Energy \& Fuels 1989, 3, 579-85. https://doi.org/10.1021/ef00017a009

[9] Keogh, R. A.; Taulbee, D. N.; Hower, J. C.; Chawla, B.; Davis, B. H. Liquefaction characteristics of the three major maceral groups separated from a single coal. Energy \& fuels 1992, 6, 614-618. https://doi.org/10.1021/ef00035a012

[10] Pickering, A.; Lester, E.; Cloke, M. Characterisation of coals for liquefaction using image analysis. In Coal Science and Technology 1995, 24, 1267-1270.

[11] Okolo, G. N.; Neomagus, H. W.; Everson, R. C.; Roberts, M. J.; Bunt, J. R.; Sakurovs, R.; Mathews, J. P. Chemical-structural properties of South African bituminous coals: Insights from wide angle XRD-carbon fraction analysis, ATR-FTIR, solid state 13C NMR, and HRTEM techniques. Fuel 2015, 158, 779-792. https://doi.org/10.1016/j.fuel.2015.06.027

[12] Everson RC, Neomagus HW, Kaitano R, Falcon R, van Alphen C, du Cann VM. Properties of high ash char particles derived from inertinite-rich coal: 1. Chemical, structural and petrographic characteristics. Fuel. 2008 Oct 1; 87(13-14):3082-90. https://doi.org/10.1016/j.fuel.2008.03.024

[13] Coetzee, S.; Neomagus, H. W.; Bunt, J. R.; Strydom, C. A.; Schobert, H. $\mathrm{H}$. Influence of potassium carbonate on the swelling propensity of South African large coal particles. Energy \& Fuels 2015, 29, 6197-6205. https://doi.org/10.1021/acs.energyfuels.5b00914

[14] Barraza, J.; Coley-Silva, E.; Piñeres, J. Effect of temperature, solvent/coal ratio and beneficiation on conversion and product distribution from direct coal liquefaction. Fuel 2016, 172, 153-159. https://doi.org/10.1016/j.fuel.2015.12.072

[15] Sehume, T. Z.; Strydom, C. A.; Bunt, J. R.; Schobert, H. H. Effectivity of Phenol during Solvent Extraction of a South African Bituminous Coal under Mild Conditions. Energy \& Fuel 2017, 31, 13655-13665. https://doi.org/10.1021/acs.energyfuels.7b01884

[16] Görling, M.; Larsson, M.; Alvfors, P. Bio-methane via fast pyrolysis of biomass. Applied energy 2013,112, 440-447. https://doi.org/10.1016/j.apenergy.2013.01.002

[17] Wang, N.; Chen, D.; Arena, U., \& He, P. Hot char-catalytic reforming of volatiles from MSW pyrolysis. Applied energy 2017, 191, 111-124. https://doi.org/10.1016/j.apenergy.2017.01.051

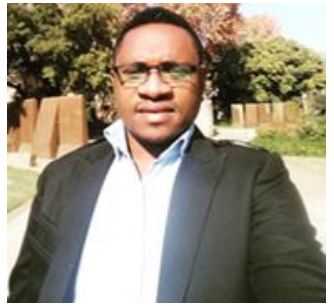

Mr Uwaoma Romanus received his BSc degree in Chemistry at the Imo state University in 2010. He obtained his Honours degree in Chemistry in 2014 and an MSc in Chemistry in 2016 from the North-West University. He is currently a $\mathrm{PhD}$ student at the Department of Chemistry, North-West University, under the supervision of Prof. Christien Strydom. His research interests are renewable energy research and improving coal utilization methods. His research is currently sponsored by the South African Research Chairs Initiative of the Department of Science and Technology and National Research Foundation of South Africa SARChI Coal Research chair grant number: 86880 and Incentive grant number: 115228 . 